
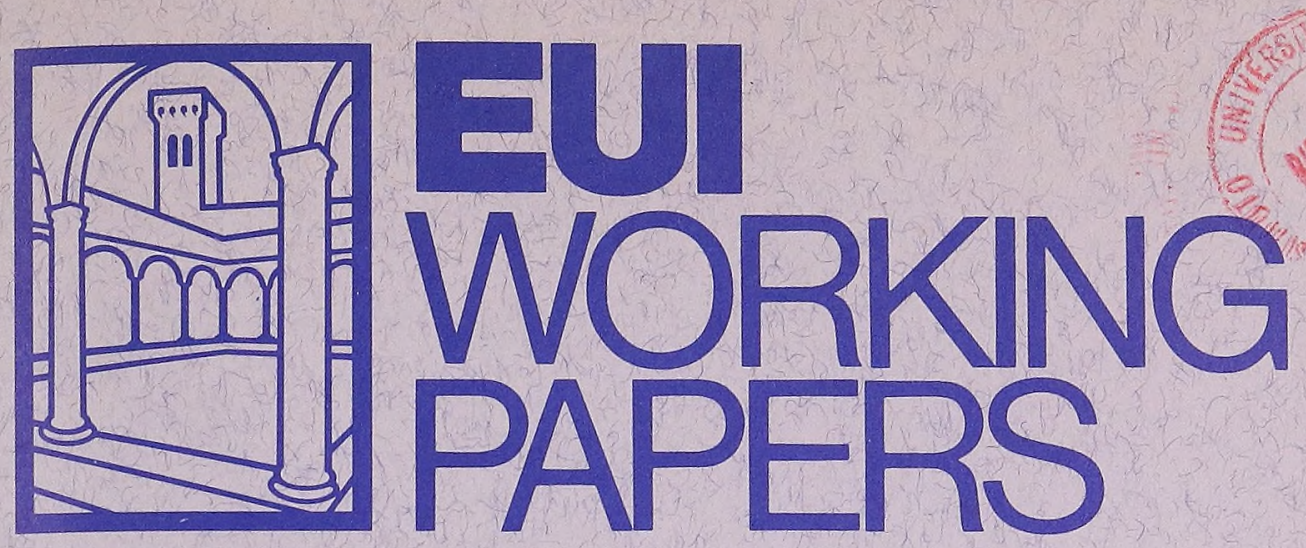

EUI WORKING P A P E R N $N^{\circ} 84 / 105$

THE ECONOMIC PERFORMANCE OF PRODUCER COOPERATIVES WITHIN COMMAND ECONOMIES :

EVIDENCE FOR THE CASE OF POLAND

by

Derek C. JONES* 
EUROPEAN UNIVERSITY INSTITUTE, FLORENCE

DEPARTMENT OF ECONOMICS

EUI WORKING P A P ER N $N^{\circ} 84 / 105$

THE ECONOMIC PERFORMANCE OF PRODUCER

COOPERATIVES WITHIN COMMAND ECONOMIES :

EVIDENCE FOR THE CASE OF POLAND

by

Derek C. JONES*

March 1984

partment of Economics

amilton College

Ninton, N.Y. 13323

Presented at Prof. D.M. Nuti's workshop on "Labour-managed firms", E.U.I., 30 March 1984.

BADIA FIESOLANA, SAN DOMENICO (FI) 
All rights reserved.

No part of this paper may be reproduced in any form without permission of the author.

(C) Derek C. Jones

Printed in Italy in July 1984

European University Institute

Badia Fiesolana

- 50016 San Domenico (Fi) -

Italy 


\title{
THE ECONOMIC PERFORMANCE OF PRODUCER COOPERATIVES
}

WITHIN COMMAND ECONOMIES: EVIDENCE FOR THE CASE OF POLAND

\author{
Derek C. Jones
}

\section{Introduction}

The principal objective of this paper is to provide evidence on important dimensions of the efficiency of producer (industrial/worker) cooperatives (PCs) within a command economy. The data are evaluated from the perspective of competing views on cooperative performance. The study is based on data for PCs belonging to the Central Union of Work Cooperatives (CZSP) in Poland. The CZSP comprises about 1500 PCS which employ about 800,000 workers, about 200,000 of whom are disabled. It accounts for about $10 \%$ of the industrial and $5 \%$ of the agricultural output of Poland. This is by far the largest PC sector in Europe, in both absolute and relative terms. The study concentrates upon a sample of industrial PCs in clothing, printing and construction for which annual enterprise level data were collected during the period 19761980. Panel data of this sort are quite scarce for command economies. Additional data have been culled from scattered Polish sources, including Polish cooperative documents.

The principal motivation for this study is the fact that little is known about the comparative performance of PCs and state owned firms within command economies. Yet such research has great potential significance in light of the recent proposals for and implementation of reforms in Eastern European economies which call for additional worker partici- 
pation (Woodall, 1982). Furthermore, while there have been a number of recent theoretical and empirical studies concerned with the performance of PCs within advanced capitalist economies, and for the Yugoslav self-managed economy, there has been no systematic study of PCs within command economies. 1 Yet it is only within command economies that PC sectors are large. Thus, in view of the keen interest by policy makers in worker participation and self-management in both East and West, ${ }^{2}$ valuable lessons may be learned from studying the Polish experience.

The paper is organized as follows. I begin with a brief historical account and a description of organizational structure. In the next part, hypotheses on cooperative performance drawn both from the formal and informal theory of the labor managed firm as well as discussions of cooperatives within command economies are presented and evaluated. This discussion is organized around two important issues: (i) the technical efficiency of Polish PCs compared to other Polish firms, and (ii) the distribution of income among PCs compared to other Polish firms. The empirical strategy is largely determined by the methods used in reference studies. (For example, when estimating the nature of income differentials among Polish PCs, the empirical analysis of Flakierski (1981) for all Polish firms is replicated for PCs alone.) The paper concludes with an interpretation of the results and a brief consideration of the research and policy implications. 
II. History and Organization ${ }^{3}$

The first known Polish industrial PC was formed in Lwow in 1873 (Kowalak, 1981) and, until the second world war, handfuls of PCs existed as part of a larger cooperative network. After 1945, though, the PC form began to flourish in Poland. Following the war, small groups of unemployed workers, usually craftsmen who used to work in highly labor-intensive industries such as textiles, clothing and leather, spontaneously established PCs so that by 1948 more than 1500 existed. This first wave of PCs were formed essentially on a voluntary basis and without a supporting institutional framework. Soon, however, a series of measures were undertaken by the state to foster the growth of PCs. PCs were sometimes seen as a complement to the preferred form of organization, that of state ownership, especially as they helped to provide jobs for unemployed workers in rural areas, who were often female. Disabled workers were another group for whom the PC form was judged by the state to be highly appropriate.

The number of industrial PCs peaked in the late $1950^{\prime} \mathrm{s}$ or early $1960^{\prime} \mathrm{s}$ at about 3400 and thereafter fell by more than half to a little over 1500 in 1978. But this reduction primarily reflects a massive merger movement. Average employment in industrial PCs has continued to grow throughout the postwar period (from 70 in 1948 to more than 500 in 1978) as has the share of industrial output and, more noticeably, the share of industrial employment which in 1978 was about $15 \%{ }^{4}$

Most PCs continue to be in light industries; textiles, clothing and leather always have accounted for about $60 \%$ of the 
share of industrial output. In these industries capital requirements are low. In 1976-1980, for example, capital-1abor ratios in sample PCs in clothing averaged about $\$ 530.00$ at the official exchange rate, less than a quarter of what it had been in similar firms in Britain in 1968 (see Table 1). Yet PCs do exist in many sectors. They account for more than $5 \%$ of industrial output in several areas including metal, precision instruments, electronics and chemicals. Polish PCs are not confined to labor intensive industries characterized by slow rates of technical change where substantial out-working remains.

By international standards (see Table 1) Polish PCs are, on average, by far the largest. Moreover, they are getting bigger. In 1976 almost $30 \%$ of Polish PCs employed more than 500 workers, almost double the fraction in 1974. Most PCs are multiplant, with industrial PCs on average having about 5 manufacturing plants and about 17 servicing establishments (Kistryn, 1980:18). Consequently, though average employment in Polish PCs has grown rapidly, average employment in plants in Polish PCs has grown much more slowly from about 16 in 1960 to 21 in 1978.

\section{Relationship with the state}

Unlike cooperatives in most Western mixed-capitalist economies (and in many other East European countries), Polish cooperatives, including PCs, receive endorsement from the Polish constitution. 5 A multitude of fairly detailed regulations provide the basic framework which governs all major aspects of the structure of PCs. 
But the most important difference between Polish coops and coops in Western mixed economies, reflects the fact that the Polish economy is centrally planned. Since 1945, most prices for inputs and outputs have been set by Polish central planners. Consequently the sovereignty of Polish PCs is severely circumscribed. The degree of sovereignty for primary PCs is particularly limited if the second and third degree PCS (the federations) such as the CZSP (see on) are regarded as having primarily played a role as arms of the planning process. In addition, the Communist Party presumably exerts some degree of political control within enterprises. But in principle at least Polish PCs have been less regimented and have had more discretion in areas such as capital use and administration. Whether or not both divisions of the socialized sector (state and cooperatively owned) have been affected equally by the planning process is an empirical matter.

\section{Internal Organization of Primary Cooperatives}

Cooperative legislation in Poland is guided by the universally recognized principles of cooperatives belonging to the International Cooperative Alliance: one member, one vote; free and voluntary membership; limited remuneration of the underwritten capital. In terms of the specific institutional arrangements within Polish PCs, this means that in principle there are a number of ways in which worker participation may operate. These may be classified into two broad categories--those channels which provide for worker participation in decision making and those features which enable workers to participate in material ways. We begin by considering the channels which provide for worker participation in 
control. First, unlike many PCs elsewhere which permit non-workers to be members, PCs in Poland only allow workers to be members. Though membership is not required of workers, in practice most workers do choose to become members. Thus, in the sample of PCs used here, an average of more than $80 \%$ of workers had assumed membership (Table 1, values of MEMB). Another channel for control follows from understanding the structure of control within Polish PCs. The main organ of de jure control is the General Assembly of members which approves the budget and decides the distribution of the surplus. The Assembly elects the members of the council, which is the body charged with formulating basic policy and is usually about twelve strong. In the sample PCs, the average council had 15 members and workers in non-managerial grades usually comprised a majority of the council (Table 1, values for WKBD). $\triangle$ management board of 3-5 members handles the daily business activi. ties of the cooperative. The board is either elected by the General Assembly or approved by the council.

Worker participation in material channels comes in two forms - in ownership and in surplus. Worker membership requires underwriting a share of the capital (net worth). In the sample of PCs, however, during 1976-1980 the average ownership stake equalled onIy about $10 \%$ of the average monthly wage. Nonetheless, capital stakes are returned in full to members when they leave the firm. Also, though payments to capital are not regarded as a cost--there is no requirement that interest be paid on the underwritten capital--in practice the payment of interest on share capital is regarded as the first charge on the surplus (profits) and the recent practice has been to pay $8 \%$. Another provision which may lead to 
this particular participation channel producing incentive effects is that, in the event of the PC sustaining a loss, losses are covered out of member's shares. That is, if a Polish PC records negative earnings, an equivalent amount is subtracted from the value of members' share capital.

If the PC makes a surplus the after tax (net) surplus is divided in two parts, a minimum of $45 \%$ of which represents the funds earmarked for development, with the balance, a maximum of 55\%, representing funds earmarked for consumption. Of the funds earmarked for consumption, not more than one half can be used as a bonus to labor. In sample PCs, an average of $28 \%$ of the net surplus was distributed in this way. Distribution is based on earnings and cannot exceed an amount equal to three months' earnings. Members who have not fully paid up their declared capital will receive at least part of their share in the surplus in the form of shares. But for the majority an amount not exceeding the value of one month's earnings is given as cash. In fact, in the sample an average amount equal to about $5 \%$ of monthly wages was distributed in this way. The balance is placed in a non-interest bearing account which members may draw upon for special reasons. The balance of the funds earmarked for consumption is used for collective consumption activities--social, educational and sporting. Of the funds earmarked for development, roughly equal amounts go to new investments in the cooperative, the cooperative's reserves and as loans which the PC is required to make to the Development Fund administered by the Central Union. Interest is paid on these loans and the central union permits member PCs to borrow on favorable terms from the Union. 
Only about 5\% of established cooperatives' assets are provided by funds which members own individually. The majority comes from the coop's collectively owned reserves and from loans from the central Union. About 20-25\% comes from loans from banks. However, bank credit is much more important in the establishment and development of new PCs.

\section{Federations (Second and Third Degree Cooperatives) and Rela- tions Among Primary Cooperatives}

We conclude this section by considering the role of the central Federation (the CZSP) and relations among PCs. AII industrial PCs in Poland are members of the CZSP which has a staff of about 400. Most of these are economists, lawyers and engineers who perform a variety of managerial tasks. Fundamentally the CZSP has a political function as a representative of the interests of PCs before the state, including the initiation of legislative proposals that concern industrial PCs. Another task is to monitor and evaluate the state of democracy in PCs. A department of self-government collects and analyzes information on matters including the size, sex, and occupational composition of the board and council and the frequency of meetings of the main organs of cooperative government. The CZSP is an economic resource center and an economic watchdog too. In addition to providing a welter of technical and economic services, such as auditing and economic analysis, the CZSP stands ready to provide assistance to member firms that are in economic distress. The CZSP administers several centralized funds. Largest is the cooperative Development Fund, the result of the pooling of loans and payments from individual PCs. Mostly these funds are used as loans to existing 
PCs, rather than as seed capital, and prevailing interest rates are paid. However, the fund is sometimes drawn upon to subsidize firms in crisis and to protect jobs. Alsc, the existence of a central pool of savings administered by a group of highly skilled professionals enables the CZSP to act as a guarantor of credit for individual PCs applying for bank loans. Other central funds finance training centers and research and development. About 90 technical schools are supervised by the CZSP. Research and development is facilitated both by the engineering staff at the CZSP and the people employed in specialized development centers at the branch level. Various other joint undertakings among PCs also exist such as design offices and common warehouses; all such institutions tend to be organized by the CZSP. Consistent with the socio-educational dimension of Polish PCS, the CZSP oversees a large network of educational, cultural, social and sporting institutions and networks.

Specialist export institutions are supervised by the CZSP. Links between PCs are developed in other ways besides member ship of the CZSP. Some industrial PCs which are engaged in similar activities, join a trade federation; such is the case with PCs in the toy industry and PCs which produce medical and laboratory apparatus. In other areas, only some PCs, usually those which export much, belong to a trade group, such as the branch union of clothing and textile PCs. Currently there are ten branch unions of industrial PCs. Industrial PCs which mainly produce for or serve the local market associate in 49 vovoid (regional) unions. A major task of vovoid unions is to help members with marketing and in providing market forecasts. Finally, cooperation between cooperatives of different kinds is 
also fostered in Poland. The Central Union, for example, has secured a long term agreement with its counterparts in retail cooperation.

\section{Theory}

Hypotheses about the behavior of PCs in command economies may be derived from two sets of economics literature. First there is a large literature written by specialists in the economies of East European economies, such as Brus (1975) and Gomulka (1982). Second there is a growing literature concerned with the economies of labor managed firms, some of which is critically reviewed by Mccain (1982). The relevance, however, for both sets of literature for the case of Polish PCs is questionable. For the East European literature in large part this doubt reflects not only a failure to develop a satisfactory theory of the socialist firm (Blazyca, 1980) but also a preoccupation with noncooperative organizations. 6 The usefulness of much theoretical work on labor managed firms for the analysis of PCs which exist often as small sectors with non-labor managed economies is doubted by many, including stephen (1982). Hence empirical work on the behavior of PCs within command economies must be guided by hypotheses drawn largely from informal theorizing within these two broad sets of literature. When this approach is adopted it, nevertheless, does result in the emergence of widely differing hypotheses. This may be illustrated by reference to issues in two broad areas of microstatic efficiency:

(i) technical efficiency; (ii) distributional efficiency. ${ }^{7}$ In each case the efficiency of Polish PCs can be evaluated with respect either to other Polish firms or PCs elsewhere. 
In the literature on East European economies, the conventional view apparently is that the centralized features of these economies along with penetration and political control within firms by the Party apparatus affects PCs and non-cooperative firms in broadly similar ways. Consequently, so the argument goes, the ostensibly distinct internal organization of PCs is in reality an empty shell. Brus (1975:36) puts it this way: ". . in practice, the real economic differences between state and cooperative forms of ownership were quickly reduced to a minimum". Consequently since PCs are expected to behave no differently than other firms, neither technical nor distributional efficiency would be expected to be affected by form of ownership or organization.

If, however, state policy has a differential impact on cooperative versus state owned firms then efficiency differences would be expected to occur. Two important illustrations come to mind. A policy favoring the state owned sector in the allocation of investment funds (KIeer, 1980) might be expected to decrease average technical efficiency, when measured by output per worker, of PCs compared to state owned firms. 8 Furthermore, unequal allocations of capital within the state owned sector (and consequently wide dispersion in capital-labor ratios) might be expected to produce larger inter-enterprise income differences among state owned firms than among PCs where investments were more evenly disbursed. Second, a policy promoting the development and extension of material incentives in PCs and their disavowal in state owned firms, would be expected by those who argue that material incentives under socialism produce a more motivated labor force (Wilcznski, 1973: Chapter 6) to result in higher 
average technical efficiency among PCs (and perhaps less distributive efficiency) compared to state owned firms. Some, however, do not believe incentive payments to be effective unless they represent at least $25 \%$ of average earnings (Fick, 1968). Others (Drewnoswski, 1982:74-83) believe incentive systems in all forms of organization in East European economies result in negligible effects when the ". . . tissue of the economic structure" has been degraded. All seemingly agree, however, that policy changes that affect both sectors equally would not be expected to produce changes in relative efficiency. 9

Turning to the theoretical economic literature that deals with participatory and labor managed firms, though much work analyzes the expected relationship between participation and performance (technical efficiency), there has been relatively little formal theorizing. Moreover, most theorizing is of limited relevance for actual PCs which differ markedly in, for example, internal organizational characteristics, between and within countries (see Estrin et al., 1983). In addition, most theorizing does not appreciate the complex nature and patterns of interaction that exist between performance and different channels of participation. Therefore again we must turn to the informal literature.

In reviewing the informal literature, one of the ways in which different authorities have approached the topic is to focus on the outcomes or the effects on performance of participation. Often the concern is with the overall or the (net) efficiency effect, and frequently the tendency is to focus on clusters of participatory channels. Two broad sets of participatory channels 
are distinguished: (i) those that operate through worker participation in decision making (as members of the entrepreneurial group or of various decision making bodies) and (ii) those that operate primarily through material incentives (e.g. participation in ownership, in surplus and in lending). 10 Broadly speaking, there are three different positions.

One group of theorists predict positive overall efficiency effects flowing from participation. Vanek $(1970,1975)$ stresses the benefits to productivity that result primarily from worker participation in decision making. For Vanek, material incentives are subordinate, but of these most important is surplus sharing. Horvat (1982) stresses the productivity effects flowing from genuine worker power also, though for him worker participation in ownership may be a practical necessity for efficient PCs. For both Vanek and Horvat, however, the full productivity effects are only realized if the PC is structured in particular ways. PCs which come closest to the optimal structure will be expected to perform best, not only as compared to other PCs but also as to non-participatory firms. Vanek's conditions for organizational efficiency may be classified into various groups of which three are most important for our purposes: (i) ultimate control and authority are vested in those who work (at a minimum this means that all workers in a $\mathrm{PC}$ are members, or $\mathrm{MEMB}=1$ ); (ii) ownership rights whereby capital owners receive a yield that reflects the scarcity price and which does not emphasize (and preferably avoids) collective ownership of assets; (iii) a shelter organization which funds and promotes the PC sector. Horvat (1982) concurs but adds another that stresses considerations of income distribution. 
Cable and Fitzroy (1980) also predict an overall positive effect of participation. But their theoretical framework stresses both material and non-material causes, and argues that there are powerful interactions, notably between surplus sharing and participation in decision making. Material incentives matter most for Oakeshott (1978) (see also Clayre, 1980). Large individually owned capital stakes are viewed as essential for generating high productivity in participatory firms.

On the pessimistic side the strongest case is made by Jensen. and Meckling (1979) who see all channels of participation as having deleterious efficiency effects. As PCs provide increasing opportunities both for worker participation in decision making and for material incentives, they predict increasing enterprise inefficiency. Inefficiencies allegedly result from worker participation in decision making in part because of the problem of preference formation when worker preferences are not identical. The monitoring argument is used to support the claim that participation in profits by workers will produce inefficiencies. They argue that as the labor force grows, each individual will have a stronger incentive to shirk; consequently shirking will become more difficult and expensive to detect. Worker participation through all channels is expected to be particularly dysfunctional in larger firms. 11

There is a third position at this general/overall level of argument. While most theorists argue as though the net efficiency effects of participation will always be of similar nature (direction) and size for all PCs, Nelson (1981) argues that, because most empirical work in this area by economists omits important 
variables (such as job satisfaction), it may be more reasonable to argue that participatory effects will differ by size, by sector, by year and by type of firm. This, therefore, is essentially a random effect, rather than a general view with varying predictions. Or it could be that there are systematic variations, but that the number of relevant variables is much higher and the patterns of interaction are much more complex than has been assumed thus far in theoretical and empirical work.

\section{Evidence}

In this section various methods are used to evaluate the economic performance of Polish PCs, mainly in the sense of static distributive and technical efficiency. Since the focus is on comparative performances, for the most part the research strategy, in particular the choice of measures, is dictated by what information is available for enterprises with which meaningful comparisons can be drawn. (Benchmark firms are other Polishstate owned firms in similar industries and other polish coops that are not worker managed.) In other words, for the sake of discussion I usually have used the same indicators for PCs and these other firms, despite the fact that they often have different goals. Some evidence is drawn from polish studies and official statistics that tend to focus on sectoral performance. But most evidence is derived from the new enterprise-level data set for a sample of Polish PCs during 1976-1980.

\section{A. Distributional Efficiency}

In Table 2, Part $A$, I present data that compare the dispersion of full-time earnings among Polish state owned firms, as 
documented by Flakierski, with comparable data for average net earnings for a sample of Polish worker cooperatives. 12 While cooperative data for 1976 and 1978 are available for three industries--construction, clothing and print--data for the overall socialized sector usually are available for these years only at higher levels of aggregation--for all firms and all industry, though separate data are available for construction.

The data enable two clear inferences to be drawn. First, average and median incomes of workers in cooperatives are considerably lower than for workers in the overall socialized sector. For example, in 1976, excluding bonus payments, an average cooperative construction worker earned $88 \%(4061 / 4633)$ of the earnings of his counterpart in the socialized sector. By 1978 the ratio had fallen to $79 \%$. Even if the monthly bonus received by cooperative workers is included, the ratio rises only to $85 \%$ (4491/5298). 13 Moreover, though data for cloth and print are not: available for the overall socialized sector, the comparative position of workers in these cooperative industries is likely to be even worse because coop construction workers typically receive about $25 \%$ more than coop workers in cloth and print, while in the socialized sector, construction workers earn only about $15-17 \%$ more than the total industry average.

The second inference is that inter-enterprise income differentials are strikingIy narrower in Polish PCs than in socialized firms as a whole. This finding is convincingly supported by all three measures of income distribution. For example, the decile ratio $\left(\mathrm{P}_{90} / \mathrm{P}_{10}\right)$ shows inequality in the three cooperative sectors ranging from 1.26 (printing, 1978) to 1.55 (cloth, 1978); in the 
socialized sector the corresponding ratios are much higher, 2.93 (industry, 1976) and 3.33 (building, 1976) respectively. Howevo er, these comparisons exclude the widening effect of including cooperative bonuses. When these are added the degree of dispersion in average incomes among coops increases and ranges from 1.43 to 1.88. But this is still far below the spreads for the socialized sector as a whole. The other indicators of inequality reveal an essentially similar pattern of narrower dispersion among PCs than among socialized firms as a whole.

There is a third, but more tentative, inference to be drawn on income inequality. Part $B$ of Table 2 shows data for PCs for a single, more recent year, 1980. Together with the data in Part A this provides some evidence that for PCs in all three sectors there has been a further narrowing of income differentials over time. For example between 1976 and 1978 the decile ratio falls from 1.52 to 1.47 in building and from 1.55 to 1.46 in clothing. The apparent decline of intrasectoral income differentials within PC sectors contrasts with the increase in intrasectoral dispersion of incomes during the 1970's within many major branches of the Polish economy (Bielasiak, 1983:227).

\section{B. Technical Efficiency}

Evaluation of technical efficiency in practice is always a difficult task. But assessing comparative technical efficiency (e.g. cooperative compared to state owned) is an especially troublesome undertaking. In the Polish case, there is evidence that, compared to state owned firms, PCs use inferior quality materials, employ older technologies, on average are smaller and 
produce with lower quality factors of production (skowronski, 1979). 14 Since the available data from which calculations of technical efficiency must be made, exclude these scale and quality considerations, inevitably the comparisons will be rough approximations of true technical efficiency. Furthermore, the neglect of these factors will tend to lead to underestimates of technical efficiency that are especially pronounced for PCs.

Against this backdrop, I begin by using data assembled by Kleer (1980) to derive comparative indicators of technical efficiency between enterprises engaged in industrial production in the overall socialized sector and in the cooperative sector during the period 1961-1978. In Part A of Table 3 I show comparisons of output per worker. Taken by themselves, these data imply that state owned firms are more productive than industrial PCs if Poland--from 1960-1978 output per worker is always higher on the average in the overall socialized sector than in PCs. This finding also coincides with the views of most casual observers including Cholaj (1979:41), who believe that labor productivity in Polish PCs is inferior to levels in state owned firms. Moreover. the apparent advantage of state owned firms seems to be growing-. the ratio of output per worker in coops to output per worker in the overall sector is falling from $87 \%$ in 1970 to $75 \%$ in 1978. But as Part $B$ of Table 3 shows, during this period fixed assets per worker in PCs averaged at most $15 \%$ of the rate per worker in the socialized sector as a whole. ${ }^{15}$ If account is taken of these much lower capital-labor ratios in PCs, and even assuming that the quality of both major inputs is the same in both sectors then, in terms of total factor productivity, PCs probably have outperformed state owned firms during this period. ${ }^{16}$ This inter- 
pretation is confirmed by one of the few attempts to conduct carefully controlled empirical studies to measure and to account for this supposed labor productivity gap, a study by skowronski (1979), who compared four state owned firms and four PCs in clothing. She found that both labor productivity, whether measured in gross or net output terms, and profitability were lower in PCs than in state owned firms. But non-labor costs per unit of output were lower and the average quality of output (as measured by comparisons of rates of substandard products) somewhat higher in PCs than in state owned firms. Skowronski explained these findings by arguing that: a) state owned firms are much more capital intensive and have prior access to newer capital equipment; and b) PCs, despite difficulties in securing regular and reliable supplies of new materials, were able to achieve lower overall costs through better organization and management and less waste. Similarly the apparent deterioration of PC comparative performance, as noted in Part A of Table 3, may be at least partially attributed to the fluctuations in rates of investment per worker between the two sectors. 17

Other data enable intra-cooperative sectoral comparisons of technical efficiency to be made, rather than the intra-socialized sectoral comparison of Table 3 . The data assembled in Table 4 compare PCs with other Polish cooperatives, i.e. coops which do not have well-developed provisions for worker participation, such as housing and retail cooperatives. These data show PCs as having a remarkable edge in technical efficiency over other cooperatives. During 1961-1978 output per worker in PCs (now broadly defined to include services) always 
exceeds the cooperative sector average by at least 67\% (in 1961). The trend is unmistakenly in the direction of a growing PC advantage. But what is most remarkable is that this growing advantage in output per worker has been achieved during a period when major inputs per worker allocated to PCs have grown much more slowly than in the overall cooperative sector. Table B shows investment (and consequently, fixed assets) per worker in PCs falling from about one third to almost one tenth of the overall cooperative sector averages. Taken together, these two trends indicate a massive advantage in technical efficiency in PCs compared to other Polish coops in which there is limited worker participation. 18

The sample data enable comparisons to be drawn between indicators for the overall economy and PC sectors during a more recent period, namely 1976-1980. Growth rates for labor and capital productivity are shown in Table 5 for sample PCs in cloth, print and building and, as calculated by Gomulka (1982) for the whole economy. With respect to labor productivity, no clear picture emerges. While in some years PCs tend to better than the overall system, this is not always true. For example, by this measure, the performance of print PCs is inferior to the whole system in both 1979--output per worker fell in printing PCs at a rate of $4.3 \%$ compared to $1.5 \%$ overall--and in 1978 , but is superior in the other two years. But during this period, PCs clearly do better from the standpoint of capital productivity. For building and printing PCs this is the case for every year and sometimes, by a large margin--in 1980 printing PCs have an advantage of more than $15 \%$. In clothing too, PCs perform well by this token, except for one year, 1978. 


\section{Conclusions}

By using an enterprise level data set on PCs for 1976-80 and various internal cooperative documents that refer mainly to $1960-$ 1978, we are able in a preliminary way to evaluate the technical and distributive efficiency of Polish PCs. All measures of inter-enterprise income distribution show, for 1976-1981, much smaller dispersion among PCs than among state owned firms. Also, there is slight evidence for PCs of a narrowing of income differences during the most recent period for which data are available, a period of major turbulence in Polish society. On the matter of technical efficiency, though the available data lack important quality dimensions and consequently comparisons usually are not as accurately made, it seems reasonable to conclude that during 1960-1980 the technical efficiency of PCs was at least as good as Polish state owned firms. Indeed, if allowance is made for the poorer quality of PC factors of production, the use of secondhand supplies and older technologies by firms that are smaller than non-participatory firms in similar industries, then it is probably reasonable to conclude that during 1960-1980 PCs were more technically efficient than other Polish firms. In particular, PCs seem to have made more efficient use of capital than state owned firms. PCs have a decided and growing advantage compared to other cooperatives.

This preliminary evidence calls into question the validity of our interpretation of the conventional academic view exemplified by the work of Brus (1975) or Gomulka (1977). This holds that systemic factors such as planning and party domination will affect PCs and other firms in broadly similar ways, such that no 
pronounced differences in technical and distributive efficiency will be expected, except insofar as state policy has a differential impact. While the authorities' emphasis on distributional and technical efficiency goals does vary over time (Woodall, 1982), and while there are important differences in policy towards PCs and state owned firms (e.g. allocation of investment funds), there is no evidence that the authorities have advocated differential policies towards PCs and other firms which would account for the particular differences in distributive and technical efficiency, which are noted in this study.

Instead the evidence offers support for the views of those (e.g. Vanek, 1975, and Horvat, 1982) who argue that worker participation in decision making and through various material incentives $^{19}$ can be expected to result in higher technical and distributive efficiency. Equally the preliminary evidence casts doubt on the views of those who predict that participatory firms will be less technically efficient than non-participatory firms. Also the variation across PC industries in the pattern of distributive and technical efficiency affords is consistent with the expectations of those who argue against a uniform and unvarying set of participatory effects, but who instead expect the effects to vary by sector and year. Alternatively, it could be that there are systematic variations, but that the number of relevant variables is much higher and the patterns of interaction are much more complicated than is implicitly assumed in the empirical part of this study. Finally the apparent growing advantage of PCs over state owned firms in 1980 in both distributive and technical efficiency is noteworthy. It is consistent with the view that environmental changes will have effects on 
enterprises that vary with the nature of the organization. As such it is at odds with those who predict such linkages between the context and the organization but who do not expect differences in effects among organizations (e.g., Brus (1975), Drewnowski (1982)) .

The above accounting for the differences in efficiency is, of course, not the only possible one. In any event it is based on preliminary evidence. In addition to tighter theoretical modeling, further empirical research is needed in a number of areas. It is most important to substantiate the factual findings of this study. Ideally such research would be based on matching enterprise level data for the various forms of Polish firms. In addition to providing for tighter controls in research design, this would enable indicators of technical efficiency such as total factor productivity to be calculated. This would provide better estimates of, for example, the extent of technical inefficiency in state owned firms, estimates which at the moment we can only make by inferences drawn from the PC data alone. A second direction for future empirical research is to undertake specific tests of hypotheses which provide competing explanations for the existence of differences in efficiency. 20 Thirdly, there is a need for future studies which would shed light on other important but currently unexplained issues such as the nature of the job and wage structures within PCs and other Polish firms and the ways in which party influence is manifested. Similar studies for other East European economies should be done to ascertain whether or not the polish case is representative for command economies. Finally, there is potentially much to be learned from careful cross national 
studies that include Polish PCs. The important similarities in the institutional arrangements within Polish and Mondragon PCs, on the one hand, and on the other hand the apparent strong performance of both organizations within each country, 21 is deserving of much more detailed investigation.

As economic and political crises continue in Poland, the tentative policy implication of the study is to expect further growth in the PC sector both in the short term and in the long term. ${ }^{22}$ In part this will result from stronger growth in the PC sector which, in turn, reflects a better economic performance of the PC sector relative to an increasingly inefficient state-owned primary sector. In part this may result from deliberate reforms, which are initiated not only because a bigger PC sector is economically attractive to the state but also because it is politically and ideologically acceptable. In particular, if the emergence of large inequalities in Polish society during the 1970's is a principal cause of the continuing Polish economic crisis (Pohorille, 1982) as well as the reason during the late 1970's and early $1980^{\prime}$ s for the politicization of the Polish working class (Bielasiak, 1983), then there are strong economic and political arguments for expanding the PC sector, a sector characterized by intra-sectoral income differentials that are modest by comparison with similar differences in the state sector. At the same time such reformism, if it continues and if it is economically successful, may feed on itself and also produce important socio-economic changes such as a flowering of de facto democracy. And since these developments would be gradual and not as conspicuous as the changes promised by the recent renewal movement, the growth of the PC sector, by promoting more subtle developments, might end up by promoting much more profound socio-economic changes. 


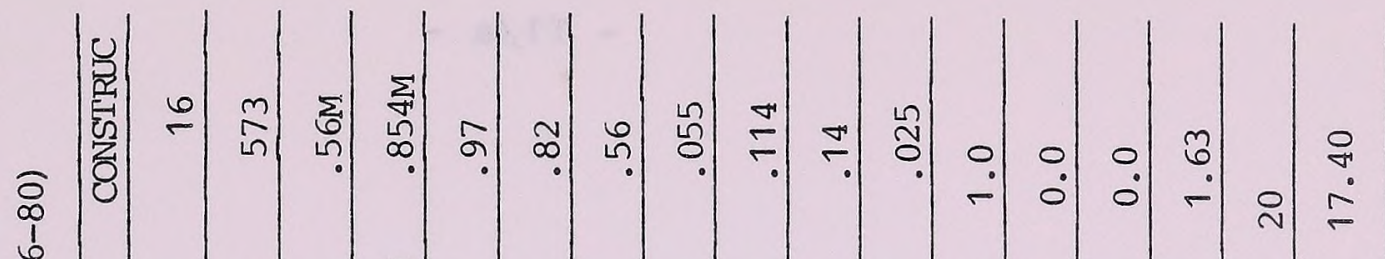

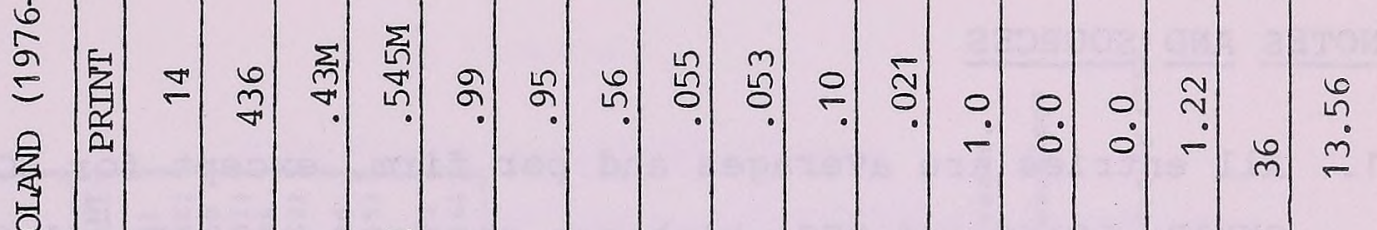

$$
\begin{aligned}
& \text { 考 m }
\end{aligned}
$$

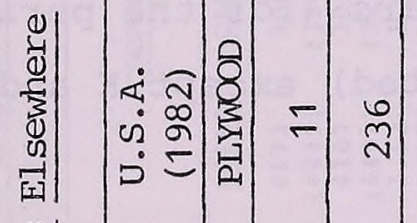

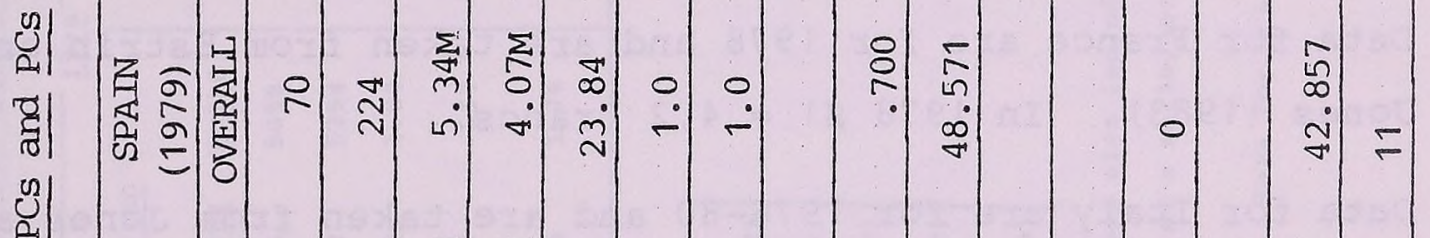

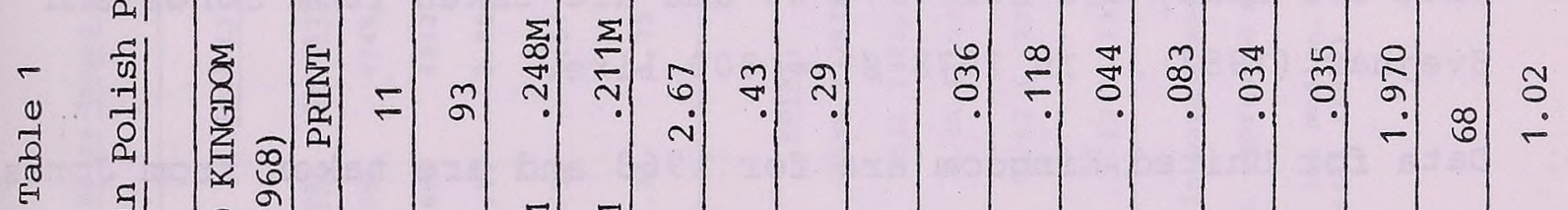

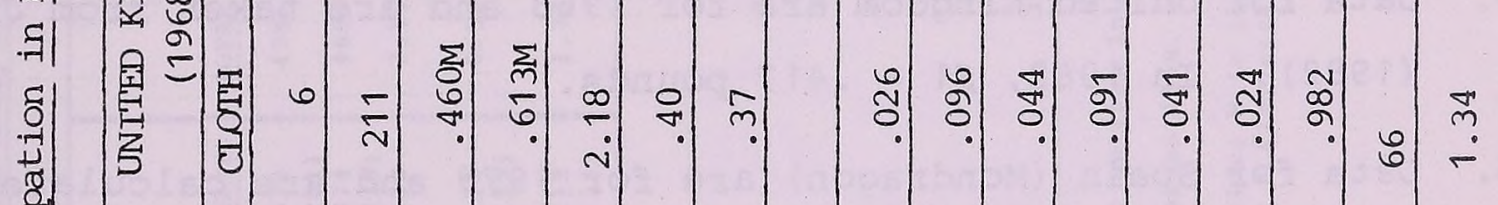

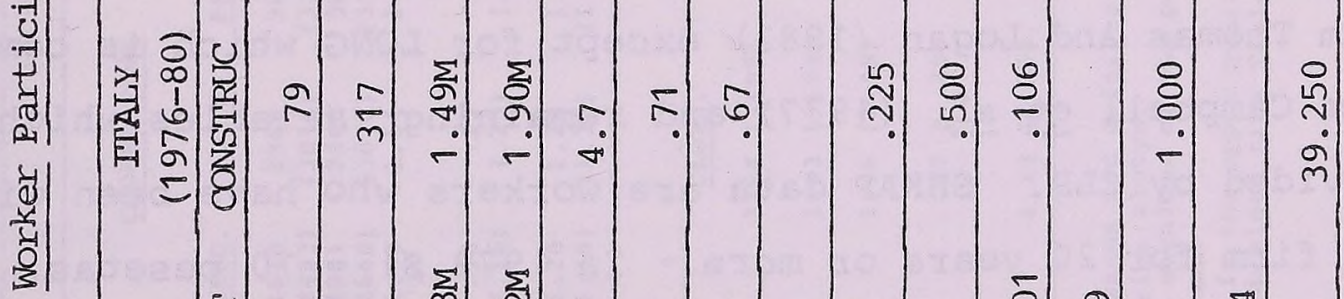

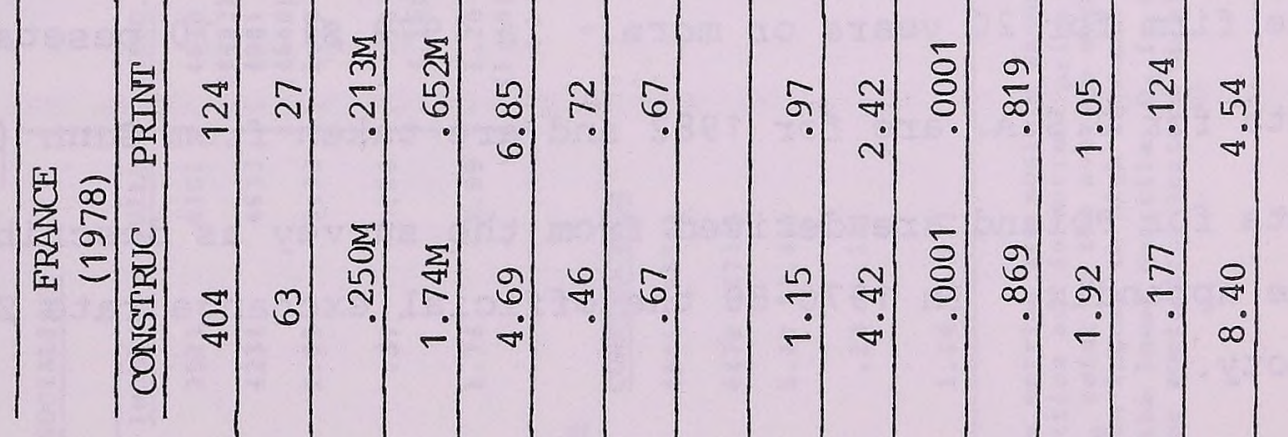

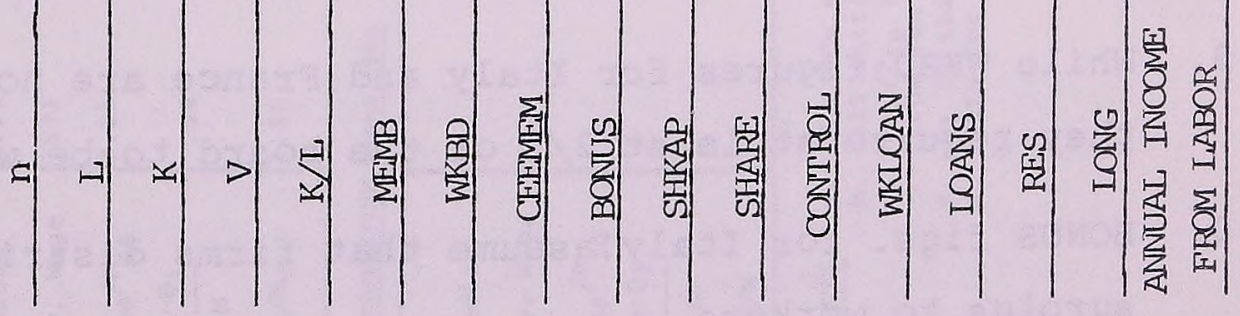




\section{NOTES AND SOURCES}

1. AII entries are averages and per firm, except for BONUS, SHRAP, LOANS and RES which are per worker. (For definitions, see Appendix.)

2. All values are in thousands of U.S. dollars (for the periods noted and using exchange rates as indicated) except $K$ and $V$ which are in millions of dollars.

3. Data for France are for 1978 and are taken from Estrin and Jones (1983). In $1978 \$ 1=4.2$ francs.

4. Data for Italy are for $1976-80$ and are taken from Jones and Svejnar (1983). In $1978 \$ 1=800$ lire.

5. Data for United Kingdom are for 1968 and are taken from Jones (1982). In $1968, \$ 1=.417$ pounds.

6. Data for Spain (Mondragon) are for 1979 and are calculated from Thomas and Logan (1982) except for LONG which is computed from Campbell et al. (1977) and remaining variables which wero provided by CLP. SHKAP data are workers who have been with the firm for 20 years or more. In $1979 \$ 1=70$ pesetas.

7. Data for U.S.A. are for 1982 and are taken from Gunn (1984).

8. Data for Poland are derived from the survey as described in the Appendix. In 1976-80 the official exchange rate $\$ 1=35$ zloty.

9. While WKBD figures for Italy and France are not available, they require at least $2 / 3$ of the board to be workers.

10. BONUS figs. for Italy assume that firms distribute $30 \%$ of the surplus to workers. 


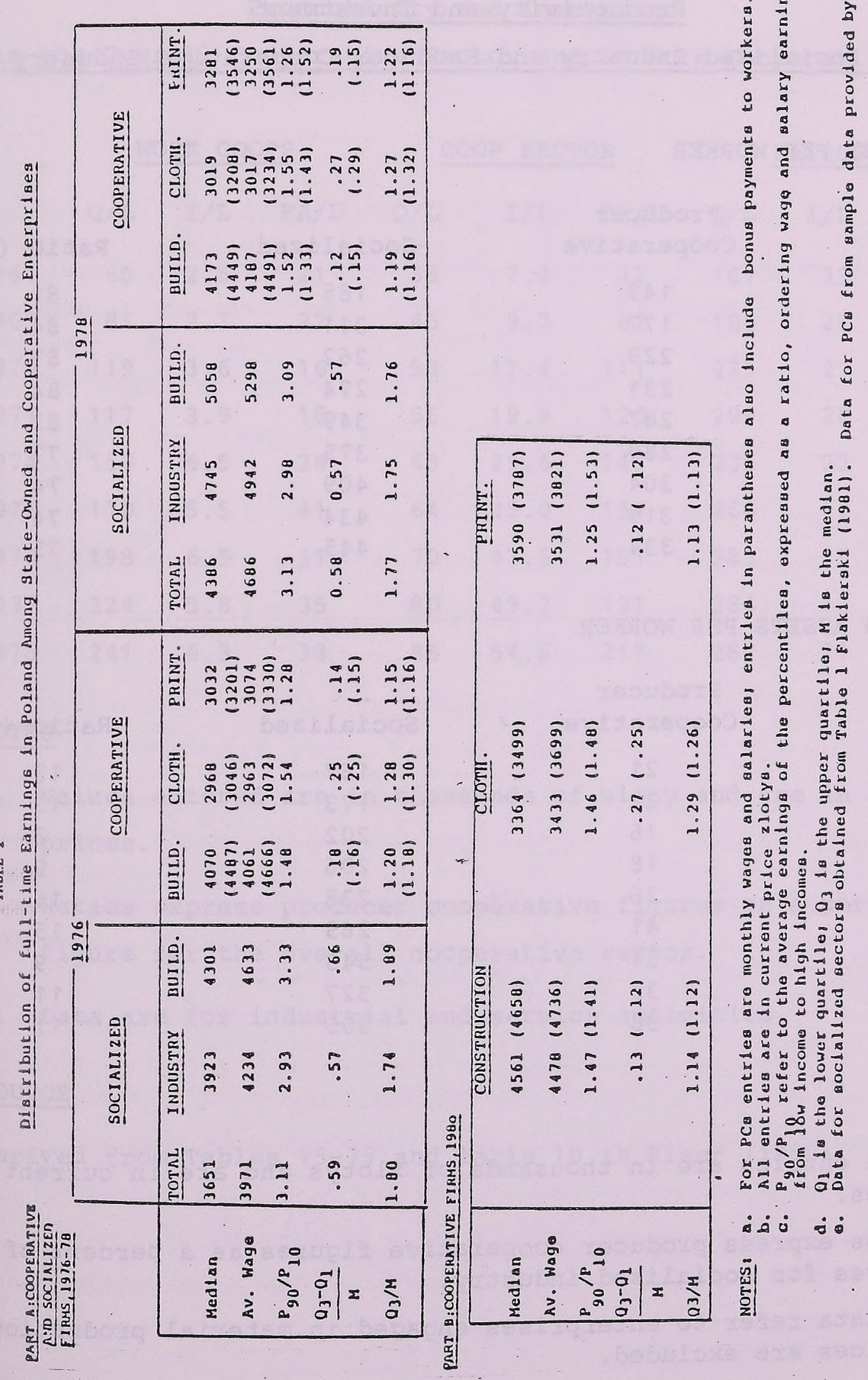


Table 3

Productivity and Investment

in Socialized Industry and Producer Cooperative Industry

A. OUTPUT PER WORKER

$\begin{array}{lccr}\text { Producer } & & \\ \text { Cooperative } & \text { Socialized } & \text { Ratio (\%) } \\ 1960 & 149 & 185 & 81 \\ 1965 & 177 & 211 & 84 \\ 1970 & 229 & 262 & 87 \\ 1971 & 231 & 274 & 84 \\ 1974 & 287 & 349 & 82 \\ 1975 & 289 & 375 & 77 \\ 1976 & 304 & 409 & 74 \\ 1977 & 319 & 434 & 74 \\ 1978 & 334 & 445 & 75\end{array}$

B. FIXED ASSETS PER WORKER

$\begin{array}{lccr}\text { Producer } & \\ \text { Cooperative } & \text { Socialized } & \text { Ratio } \\ 1960 & 21 & 167 & 13 \\ 1965 & 22 & 173 & 13 \\ 1970 & 16 & 202 & 8 \\ 1971 & 18 & 206 & 9 \\ 1974 & 26 & 238 & 11 \\ 1975 & 41 & 265 & 15 \\ 1976 & 31 & 343 & 9 \\ 1977 & 35 & 327 & 11 \\ 1978 & 38 & 355 & 11\end{array}$

\section{Notes}

1. Value entries are in thousands of zlotys and are in current prices.

2. Ratios express producer cooperative figures as a percent of figures for socialized industry.

3. All data refer to enterprises engaged in material production; services are excluded.

Source: Derived from Tables $8-11,15-17$, and 75 and 78 in Kleer (1980). 
Table 4

Productivity and Investment

in the Overall Cooperative Sector and in Work Cooperatives

WORK COOPS

Q/I I/L FA/L

$Q / \mathrm{L}$

COOP SECTOR

$I / L \quad F A / L$

$Q / L$

RATIOS

$\begin{array}{rrrrrrrrrr}1961 & 65 & 2.5 & 21 & 39 & 7.4 & 42 & 167 & 33 & 50 \\ 1965 & 81 & 2.3 & 22 & 45 & 9.2 & 62 & 180 & 25 & 35 \\ 1970 & 119 & 3.6 & 16 & 53 & 17.4 & 111 & 225 & 21 & 14 \\ 1971 & 117 & 3.9 & 18 & 56 & 19.9 & 120 & 209 & 20 & 15 \\ 1974 & 150 & 6.5 & 26 & 63 & 29.6 & 148 & 238 & 22 & 18 \\ 1975 & 170 & 5.5 & 41 & 64 & 35.0 & 154 & 266 & 16 & 27 \\ 1976 & 198 & 6.5 & 31 & 70 & 43.5 & 151 & 283 & 15 & 21 \\ 1977 & 224 & 5.8 & 35 & 80 & 49.7 & 191 & 284 & 12 & 18 \\ 1978 & 241 & 6.3 & 38 & 85 & 54.8 & 219 & 284 & 11 & 17\end{array}$

\section{NOTES}

1. Values entered are in thousands of zloty and are in current prices.

2. Ratios express producer cooperative figures on a percent of figure for the overall cooperative sector.

3. Data are for industrial and service activities.

SOURCE

Derived from Tables $75-79$ and Table 10 in Kleer (1980). 

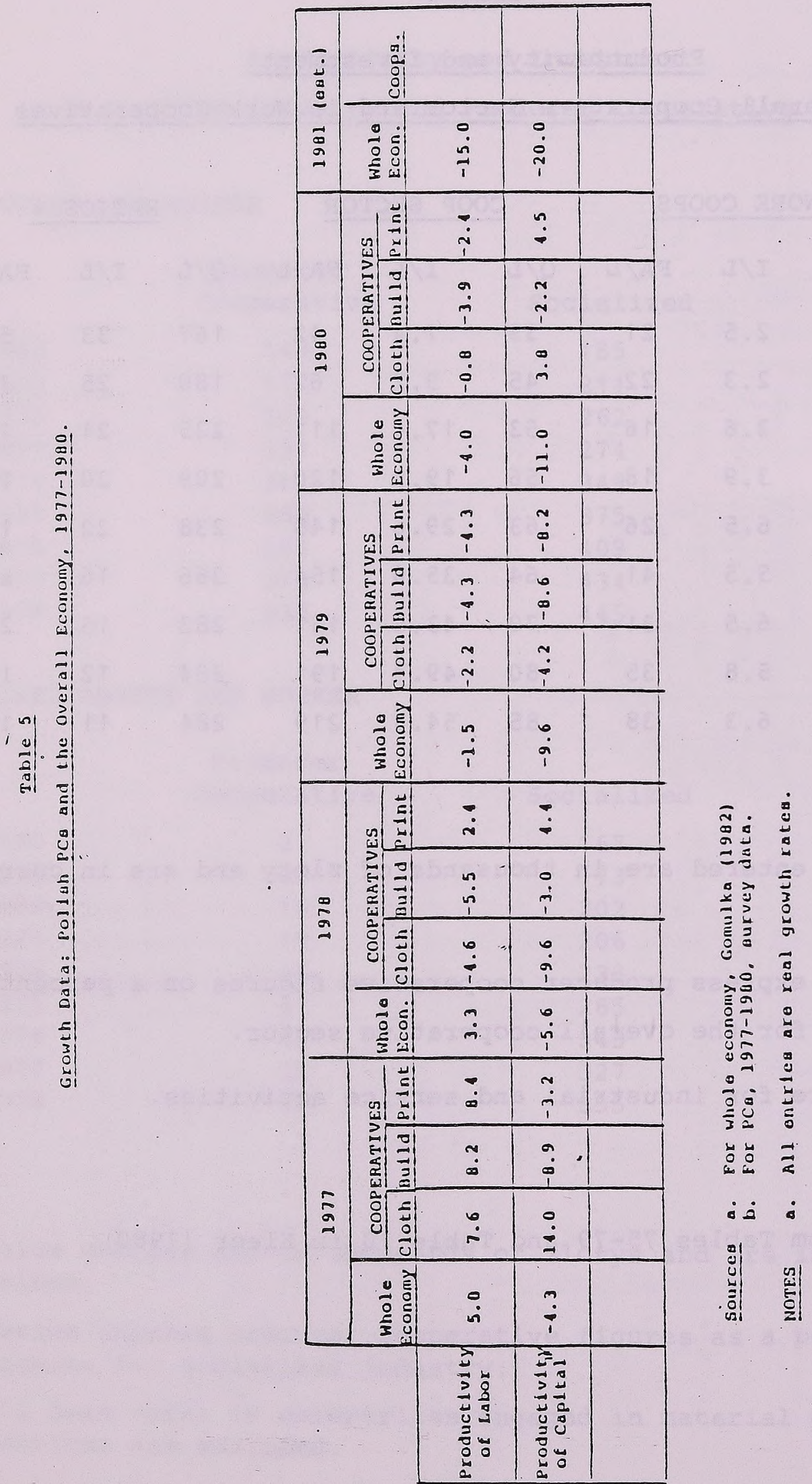


\section{Notes:}

1. For empirical evaluations of the performance of PCs and the Yugoslav self-managed system, see Jones and Svejnar (eds.) (1982).

2. Note in particular that the Polish system of PCs has been advanced as a development model and for imitation as a means of aiding the disabled. (See I.L.O., 1978, 1980.)

3. For expanded amounts of the institutional framework see Jones (1984) and Kowalak (1981).

4. Since 1960 the continued growth in the size of the industrial PC sector has been sustained by the development of an important Polish species of industrial PC, namely cooperatives for the disabled. Their growth reflects early successes in rehabilitation, as well as providing jobs mainly for war invalids. This, in turn, led to the state in 1959 introducing measures which both encouraged the development of an institutional support system and provided the financial wherewithal to facilitate such growth. See I.L.O., 1978.

5. Article II expresses the state's desire to promote cooperatives and promises to provide state assistance in that task.

6. But for an exception see Kornai (1980). Also, while I believe that East European specialists have not published much theoretical work in English on cooperatives (Yugoslavia excepted), there may be rich non-English literature that I am unaware of. 
7. A firm is considered to be technically more efficient than another if, for a given input(s) it produces more output. While this definition is not too controversial, as Buck (1982:4) notes, there is no general agreement on the exact meaning of distributive efficiency. Here we follow Buck and define distributive efficiency as the degree to which the actual distribution of income corresponds to the supposed desirable distribution. I focus discussion on these particular components of economic efficiency because of their importance in the literature on Eastern European economies.

8. Those policies introduced in the early 1970's that promoted the development of larger productive units (see Wanless, 1980, would be expected to lead to bigger changes in the average size of firms in the state owned sector, compared to firms, including PCs, in the cooperative sector. Therefore, to the extent that returns to scale exist, the differential impact of this policy would be expected, other things equal, to improve the relative technical efficiency of state owned compared to cooperative firms.

9. This is not to say that efficiency would be unaffected by policy changes. Brus (1975:191), for example, would expect those policy changes producing greater political participation outside enterprise to be associated with higher efficiency within enterprises. Gomulka (1977) too expects a similar relationship though his view of the precise nature of the causal linkages differs much from that of Brus. Both agree, however, that because of étatization within firms, policy changes of this kind would not have differential effects on PCs and state owned firms. 
10. In some literature, the main interest has been to consider the particular ways in which participation could be expected to cause changes in efficiency. For a review of some of these arguments see Jones and Svejnar (1982).

11. In the context of a centrally planned economy, however, it is likely that Jensen and Meckling would modify the thrust of their argument.

12. I do not report comparisons using more extreme indicators of income inequalities, such as $\mathrm{P}_{98} / \mathrm{P}_{2}$, because of the limited number of observations available for PCs.

13. Both measures are calculated since it is not obvious which measure is used by Flakierski.

14. Both the quality of labor and capital is lower in Polish PCs than in state-owned firms, in part because the planning process is much more sensitive to the needs of state-owned firms. For example, it is unlikely that much of the capital imported into Poland during the 1970's ended up in PCs. The employment of many relatively unskilled people and disabled workers in PCs inevitably tends to depress the average quality of labor.

15. The figures for PCs are for net fixed assets whereas for the overall socialized sector, only gross value figures are available. This procedure will tend to exaggerate reported (net fixed assets) PC capital-labor ratios by about $10 \%$ over what they would have been if gross value data were available. In other words, the ratio figures, whereby PC capital-labor ratios are expressed as a percentage of figures for all socialized industry, probably represent an upper limit estimate of the true ratios. 
16. Since the labor/output ratio is higher and the capital/output ratio is smaller in PCs, the joint productivity depends on the size of the capital weights used. Though these data are not available, using capital weights in the usual ranges confirms higher technical efficiency in PCs.

17. During 1961-65 investment per worker in PCs amounted to about 24,000 zloty, roughly $31 \%$ of the corresponding figures for the overall socialized sector. During 1966-70 the corresponding figures were 32,000 zloty $(30 \%)$, in 1971-75 60,000 (36\%) and. in 1976-1978, 47,000 (27\%). Figures derived from Tables 17of Kleer (1980).

18. Various writers suggest that prices received by producers in PCs are closer to market prices than in the non PC segment of the cooperative sector. If so, this would account for some of the apparent PC advantage, though surely not all.

19. In Jones (1983) I present more detailed information on the nature and scope of worker participation in Polish PCs. I ten. tatively conclude that the variety of channels that exist to provide for worker participation in Polish PCs do both facilitate a measure of worker influence in decision making and constitute a series of economic incentives.

20. For example, the author is currently undertaking an economic study of Polish PCs in which competing hypotheses on the technical efficiency effects of worker participation are tested. For sample PCs, where variable values for the different channels of participation vary widely, I plan to estimate the productivity effects of different degrees of worker participation in different forms. 
21. For the Mondragon case see Thomas and Logan (1982).

22. In another paper (Jones, 1982a) I develop and advance this argument for the whole cooperative sector in Poland. 


\section{The Data and the Variables}

\section{APPENDIX}

\section{A. The Data}

The data were made available to Jones by officials of the CZSP during work which was funded in part, and as part of a larger project, by the Leverhulme Trust. Data analysis was undertaken while the author was a German Marshall Fund Fellow.

The data were gathered in a survey using an instrument designed by Jones and administered by officials of the CZSP, the or. ganization to which all Polish PCs belonged in 1981. For each of three industries--cloth, print and construction--societies to be surveyed were selected randomly from lists of members. These industries were selected in large part because of their importance in Polish industry. For example in 1980 Polish clothing PCs accounted for about $42 \%$ and printing for about $39 \%$ of that industry's output (Table 2). Only societies which were neither agricultural nor coops for disabled were sampled. In 1980, there were about 1100 PCs of this type. The sample comprised 63 PCs and data were gathered for 5 years.

\section{B. Variables}

MEMB = Proportion of the labor force that are worker members.

CEEMEM = Proportion of the membership that serve on a committee.

WKBD = Proportion of the board that are production and service workers. 


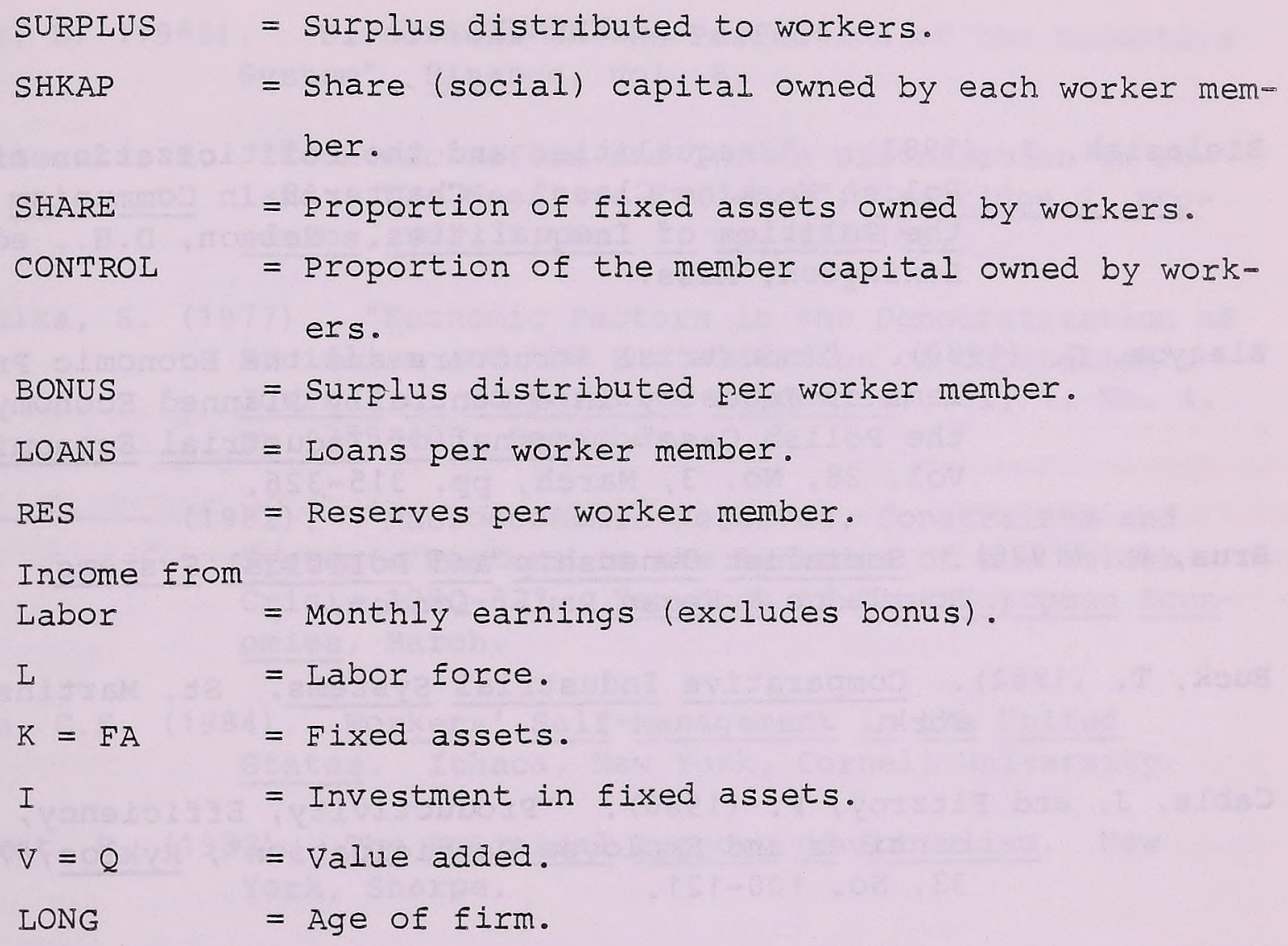


REFERENCES

Bielasiak, J. (1983). "Inequalities and the Politicization of the Polish Working Class". Chapter 9 in Communism and the Politics of Inequalities. Nelson, D.H., editor, Lexington, Mass.

Blazyca, G. (1980). "Industrial structure and the Economic Problems of Industry in a Centrally Planned Economy: the Polish Case", Journal of Industrial Economics, Vol. 28, No. 3, March, pp. $315-326$.

Brus, W. (1975). Socialist Ownership and political systems. Routledge \& Kegan Paul, London.

Buck, T. (1982). Comparative Industrial Systems. St. Martins, New York.

Cable, J. and Fitzroy, F. (1980). "Productivity, Efficiency, Incentives and Employee Participation", Kyklos, Vol. 33 , No. $100-121$.

Campbell, A. et al. (1977). Worker Ownership: The Mondragon Achievement. London, Anglo German Foundation.

Cholaj, H. (1979). "Producer Cooperatives in Poland", Oeconomica Polona, Vol. VI, No. 1, pp. 21-44.

Drewnoswski, J. (1982). "The Anatomy of Economic Failure in Soviet Type systems" in J. Drewnoswski (ed.), Crisis in the Polish Economy, Croom Helm, Kent.

Estrin, S. and Jones, D.C. (1982). "The Effects of worker Participation Upon Productivity in French Producer Cooperatives". Working Paper No. 68, Department of Economics, European University Institute (Florence).

Forthcoming in International Journal of Industrial Organization.

Svejnar, J. (1983). "The Varying Nature, Importance and Productivity Effects of Worker Participation: Evidence for Contemporary Producer Cooperatives in Industrialized Economies". Unpublished manuscript, Dept. of Economics, Hamilton College. 
Fick, B. (1968). "Directions in the Perfection of the Incentive System", Finance, Vol. 8.

Flakierski, H. "Economic Reform and Income Distribution in Poland: The Negative Evidence", Cambridge J. Economics, Vol. 5, No. 1, pp. 137-158.

Gomulka, S. (1977). "Economic Factors in the Democratization of Socialism and the Socialization of Capitalism", Journal of Comparative Economics, Vol. 1, No.4, pp. 389-406, December.

(1982). "Macroeconomic Reserves, Constraints and Systemic Factors in the Dynamics of the Polish Crisis 1980-82". Yearbook of East European Economies, March.

Gunn, C.E. (1984). Workers' Self-Management in the United States. Ithaca, New York, Cornell University.

Horvat, B. (1982). The Political Economy of Socialism. New York, Sharpe.

I.L.O. (1978). Co-operatives for the Disabled: Organization and Development, I.I.O. , Geneva.

(1980). Work for the Disabled: Vocational Rehabilitation and Employment Creation. Stockholm: Departmenteus offsetcentral.

Jensen, M.C. and Meckling, W.H. (1979). "Rights and Production Functions: An Application to Labor-Managed Firms and Codetermination", Journal of Business, Vol. 52, No. 4, pp. 409-506.

Jones, D.C. (1982). "British Producer Cooperatives 1948-1968: Productivity and Organizational structure" in Jones and Svejnar, eds.

(1982a). "The Cooperative sector in Postwar Poland". Paper prepared for presentation at CES conference of Europeanists, April 1982, Washington. 
Jones, D.C. (1983). "Participation in Worker Cooperatives in Command Economies: The Case of Poland". Forthcoming in Vol. III, Yearbook of Organizational Democracy, R. Stern (ed.), Wiley.

and Svejnar, J. (eds.) (1982). Participatory and Self-Managed Firms: Evaluating Economic Performance. Lexington, Mass., Heath.

(1982b). "Participation, Profit Sharing, Worker Ownership and Efficiency in Italian Producer Cooperatives". Working Paper No. 283, Department of Economics, Cornel University.

Kistryn, T. (1980). "Organization and Functioning of Work Cooper atives in Poland". Pamphlet, pp. 1-60. Warsaw: Supreme Cooperative Council.

Kornai, J. (1980). Economics of Shortages (North Holland).

Kowalak, T. (1981). "Work Cooperatives in Poland". Unpublished manuscript presented at the International Conference on Producer Cooperatives, Gilleleje, Denmark, May 31 - June 4.

Mccain, R. (1982). "Empirical Implications of Worker Participation in Management" in Jones and Svejnar, eds.

Nelson, R. (1981). "Research on Productivity Growth and Differences", $\underline{J} \cdot \underline{E} \cdot \underline{I}$. , Vol. XIX, No. 3, Sept., 1029-1064.

Nuti, D.M. (1982). "The Polish Crisis: Economic Factors and Constraints" in Drewnowski, J. (ed.), Crisis in the Polish Economy. Croom Helm, Kent.

Oakeshott, R. (1978). The Case for Workers Cooperatives. Routledge \& Kegan Paul.

Pohorille, M. (1982). "Questions of Income Distribution in Poland", Economic and Industrial Democracy, No. 3, pp. $159-176$.

Skowronski, S. (1979). "The Effectiveness of Economic Activity in Big and Small Enterprises (Productive Co-operatives)" , Cooperative Scientific Quarterly, 1979

(2), pp. 12-16. 
Stephen, F.H. (ed.) (1982). "The Economic Theory of Labour Managed Firms" in Stephen, F.H. (ed.), The Performance of Labour Managed Firms. St. Martins Press, New York.

Thomas, H. and Logan, C. (1982). Mondragon: An Economic Analysis. London: Allen and Unwin.

Vanek, J. (1970). The General Theory of Labor Managed Market Economies. Ithaca, New York, Cornell University Press.

-...... (ed.) (1975). Self-Management: Economic Liberation of Man. London: Penguin.

Wanless, P.T. (1980). "Economic Reform in Poland, 1973-1979", Soviet studies, Vol. XXXII, No. 1, pp. 28-57.

Wilczynski (1973). Profit, Risk and Incentives Under Socialist Economic Planning. Harper \& Row, New York. 
No. 1: Jacques PELKMANS

No. 3: Aldo RUSTICHINI

No. 9: Manfred E. STREIT

No. 10: Kumaraswamy VELUPILLAI

No. 11: Kumaraswamy VELUPILLAI

No. 12: Kumaraswamy VELUPILLAI Guglielmo CHIODI

No, 22: Don PATINKIN

No. 23: Marcello DE CECCO

No. 24: Marcello DE CECCO

No. 25: Manfred E. STREIT

No. 34: Jean-Paul FITOUSSI

No. 35: Richard M. GOODWIN Kumaraswamy VELUPILLAI

No. 46: Alessandra VENTURINI

No. 47: Richard M. GOODWIN

No. 48: Jean-Paul FITOUSSI Danie1 SZPIRO

No. 56: Berc RUSTEM Kumaraswamy VELUPILLAI

No. 60: Jean-Paul FITOUSSI

No. 64: Marce110 DE CECCO
The European Community and the Newly Industrialized Countries

Seasonality in Eurodollar Interest Rates

Information Processing in Futures Markets. An Essay on the Adequacy of an Abstraction.

When Workers Save and Invest: Some Kaldorian Dynamics

A Neo-Cambridge Model of Income Distribution and Unemployment

On Lindahl's Theory of Distribution Pau1 A. Samuelson on Monetary Theory

Inflation and Structural Change in the Euro-Dollar Market

The Vicious/Virtuous Circle Debate in the '20s and the ' 70 s

Modelling, Managing and Monitoring Futures Trading: Frontiers of Analytical Inquiry

Modern Macroeconomic Theory; an Overview

Economic Systems and their Regulation

Is the Bargaining Theory Still an Effective Framework of Analysis for Strike Patterns in Europe?

Schumpeter: The Man I Knew

Politique de $I^{\prime}$ Emploi et Réduction de la Durée du Travail

Preferences in Policy Optimization and Optimal Economic Policy

Adjusting to Competitive Depression. The Case of the Reduction in Working Time

Italian Monetary Policy in the 1980 s 
No. 1: Jacques PELKMANS

No. 3: Aldo RUSTICHINI

No. 9: Manfred E. STREIT

No. 10: Kumaraswamy VELUPILLAI

No. 11: Kumaraswamy VELUPILLAI

No. 12: Kumaraswamy VELUPILLAI Guglielmo CHIODI

No. 22: Don PATINKIN

No. 23: Marce11o DE CECCO

No. 24: Marcello DE CECCO

No. 25: Manfred E. STREIT

No. 34: Jean-Pau1 FITOUSSI

No. 35: Richard M. GOODWIN Kumaraswamy VELUPILLAI

No. 46: Alessandra VENTURINI

No. 47: Richard M. GOODWIN

No. 48: Jean-Paul FITOUSSI Danie1 SZPIRO

No. 56: Berc RUSTEM Kumaraswamy VELUPILLAI

No. 60: Jean-Pau1 FITOUSSI

No. 64: Marce110 DE CECCO
The European Community and the Newly Industrialized Countries

Seasonality in Eurodollar Interest Rates

Information Processing in Futures Markets. An Essay on the Adequacy of an Abstraction.

When Workers Save and Invest: Some Kaldorian Dynamics

A Neo-Cambridge Model of Income Distribution and Unemployment

On Lindahl's Theory of Distribution

Paul A. Samuelson on Monetary Theory

Inflation and Structural Change in the Euro-Do1lar Market

The Vicious/Virtuous Circle Debate in the ' 20 s and the 170 s

Modelling, Managing and Monitoring Futures Trading: Frontiers of Analytical Inquiry

Modern Macroeconomic Theory; an Overview

Economic Systems and their Regulation

Is the Bargaining Theory Still an Effective Framework of Analysis for Strike Patterns in Europe?

Schumpeter: The Man I Knew

Politique de I'Emploi et Réduction de la Durée du Travail

Preferences in Policy Optimization and Optimal Economic Policy

Adjusting to Competitive Depression. The Case of the Reduction in Working Time

Italian Monetary Policy in the 1980 s 